\title{
Mycobacterium avium pelvic abscess with vaginocutaneous fistula after transobturatory sling surgery
}

\author{
Abscesso pélvico por Mycobacterium avium com fístula vaginocutânea \\ após sling transobturatório
}

\begin{abstract}
Ricardo Vieira Teles Filho ${ }^{1}$, Guilherme de Matos Abe ${ }^{2}$, Lucas Henrique Souza de Azevêdo ${ }^{3}$, Gabriela Daldat ${ }^{4}$
\end{abstract}

Teles Filho RV, Abe GM, Azevêdo LHS, Daldat G. Mycobacterium avium pelvic abscess with vaginocutaneous fistula after transobturatory sling surgery / Abscesso pélvico por Mycobacterium avium com fístula vaginocutânea após sling transobturatório. Rev Med (São Paulo). 2021 Nov-Dec;100(6):605-8.

\begin{abstract}
This study presents a rare case of abscess associated with vaginocutaneous fistula due to atypical mycobacterial infection after sling surgery, which was successfully treated. Abscesses and fistulas are rare postoperative complications in treatment of stress urinary incontinence by transobturatory sling surgery, due to its high rate of positive outcomes in the treatment of urinary incontinence in women. These complications are considered to be related to the composition of the mesh and bacterial infection. We report a case of a 50-year-old patient who developed, in the 7 th postoperative year of perineoplasty with sling placement, pelvic abscess and cutaneous fistula in the left thigh. Microbiological examination of the lesion revealed infection by Mycobacterium avium. Antibiotic therapy plus abscess drainage surgery and surgical correction of the fistulous pathway were the treatment of choice. During the surgery, a vaginal opening of the cutaneous fistula was evidenced, originating from the sling mesh, which was removed and later proved to be colonized by M. avium. The patient became asymptomatic after 1 year of postoperative follow-up.
\end{abstract}

keywords: Pelvic abscess; Mycobacteriosis; Fistula.
RESUMO: Este estudo apresenta um caso raro de abscesso associado à fístula vaginocutânea devido a infecção micobacteriana atípica após sling transobturatório, que foi tratada com sucesso. Abscessos e fístulas são raras complicações pós-operatórias na cirurgia de correção de incontinência urinária de esforço por meio de implante via transobturatória, devido à sua alta taxa de resultados positivos no tratamento da incontinência urinária em mulheres. Essas complicações são consideradas relacionadas à composição da malha e infecção bacteriana. Relatamos um caso de um paciente de 50 anos que desenvolveu, no sétimo ano pós-operatório de perineoplastia com colocação de sling, abscesso pélvico e fístula cutânea na coxa esquerda. O exame microbiológico da lesão revelou infecção por Mycobacterium avium. A terapia antibiótica mais a cirurgia de drenagem do abscesso e a correção cirúrgica da via fistulosa foram o tratamento de escolha. Durante a cirurgia, foi evidenciada uma abertura vaginal da fístula cutânea, originária da tela tipo sling, que foi removida e posteriormente comprovada como colonizada por M. avium. A paciente tornou-se assintomática após 1 ano de seguimento pós-operatório.

Palavras-chave: Abscesso pélvico; Micobacteriose; Fístula.

1.Universidade Federal de Goiás. http://orcid.org/0000-0003-4822-1526; ricardovteles@gmail.com.

2. Universidade Federal de Goiás. https://orcid.org/0000-0002-2446-3750; guimatosabe@gmail.com.

3. Universidade Federal de Goiás. https://orcid.org/0000-0002-2629-492X; lucasvedo42@gmail.com.

4. Universidade Federal de Goiás. https://orcid.org/0000-0001-9170-1731; gabidaldat@hotmail.com.

Correspondence: Ricardo Vieira Teles Filho. Universidade Federal de Goiás. Avenida dos Alpes; nº 499, Setor União, Goiânia-GO, Brasil. CEP:

74313-760. Email: ricardovteles@gmail.com. 


\section{INTRODUCTION}

$\mathrm{T}$ ransobturatory sling surgery for the treatment of urinary incontinence has high rates of positive outcomes and low rates of infectious complications. Late fistulas originating from pelvic abscesses may be related to displacement or extrusion of the mesh (the pelvic sling), but they are a rare entity. The most common occurrences of infections with non-tuberculous mycobacteria (NTM) are noticed in cutaneous sites, especially surgical site infections. Hernia repairs, laparoscopic surgeries and skin grafts are procedures that carry a risk of infection by NTM due to the characteristic of being biofilm-forming, however, in spite of this, the cases described in the literature are rare.

One of the most frequent etiologies in cases of surgical site infection is Mycobacterium fortuitum ${ }^{1}$. Only two cases of post-surgical sling infection by Mycobacterium fortuitum and Mycobacterium chelonae were found in literature, but both cases followed suspension surgery with frontal sling for ptosis treatment ${ }^{2,3}$. It was not possible to find any case of post-surgical infection by any species of the genus Mycobacterium in transobturatory sling surgery.

Therefore, this paper presents a rare case of pelvic abscess due to Mycobacterium avium (MA) transobturatory sling infection that evolved with recurrent fistulization, culminating in the occurrence of a vaginocutaneous fistula.

\section{CASE REPORT}

A 50-year-old female patient underwent hysterectomy 10 years ago along with perineoplasty with the placement of a transobturatory sling. After 7 years, she presented with an abscess in the pelvic region, with cutaneous fistulization to the medial surface of the upper third of the left thigh. Following the investigation, Mycobacterium avium was isolated in a sample taken from the abscess, prompting treatment with antimycobacterial antibiotic therapy (rifampicin, ethambutol and azithromycin) for 10 months, which did not resolve the case. The investigation was then complemented with computed tomography of the lower abdomen and lower limb, which showed signs of an inflammatory process compromising the muscular planes of the proximal third of the left thigh with extension to the pelvic floor region, with an organized intramuscular collection suggesting an abscess between adductors and gracilis muscle, $13.3 \times 2.6 \times 1.6 \mathrm{~cm}$ long, as well as a small collection located in the topography of the pelvic floor, in addition to inguinal lymph node enlargement. Surgical approach was then decided, having the abscess drained by open surgery through a longitudinal incision in the abscess region, alongside debridement of the region. During the surgery, fistulous tract catheterization was performed with nelaton 6.0, and a methylene blue test later showed a vaginal cutaneous fistula tract, with an ostium at 3 o'clock. in the left lateral region of the vaginal wall. While approaching the fistula, the presence of a foreign body similar to the mesh was identified in the pelvic floor musculature, and the subsequent anatomopathological examination confirmed that it was the polypropylene mesh colonized by MA (Figure 1); It was not possible to identify the brand manufacturer of the sling, as the surgery was performed at another associated service without registration of the brand used. The mesh was completely removed on the affected side and the antimycobacterial antibiotic therapy was continued, the same, guided according to antibiogram. The patient evolved asymptomatically after the surgery without recurrence of the abscess and without new fistulas after 1 year of follow-up; and no recurrence of urinary symptoms either after surgery.

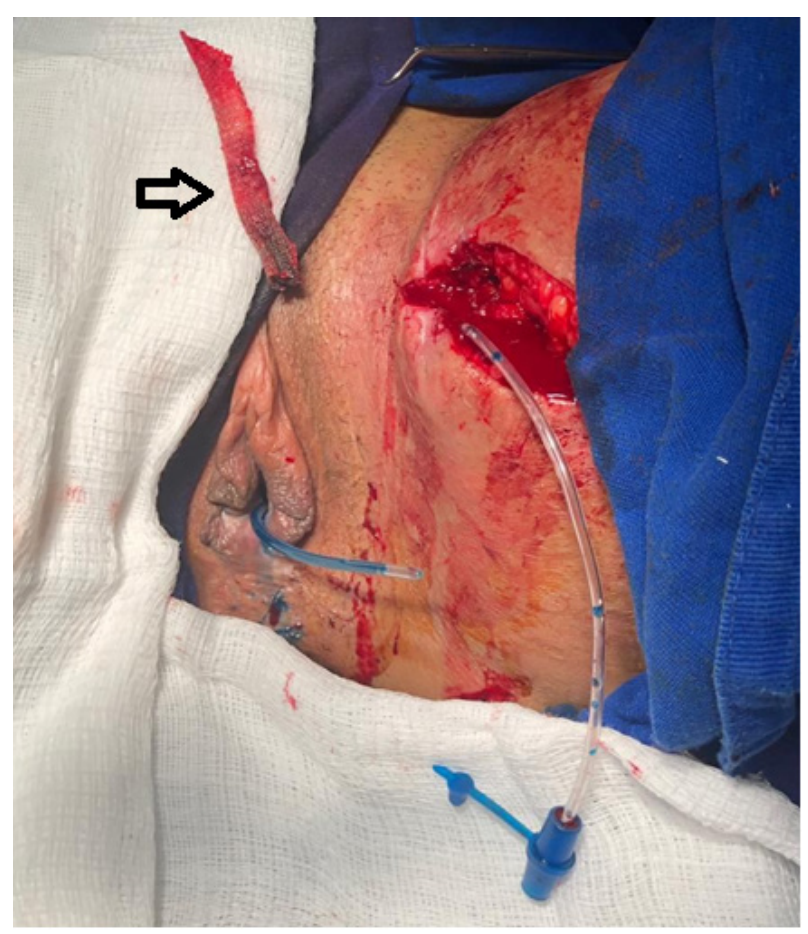

Figure 1: Intraoperative disclosure of the vaginocutaneous fistula after insertion of methylene blue in the fistulous path. Arrow: Sling removed.

\section{DISCUSSION}

The treatment of urinary incontinence in the last decade has been widely performed through transobturatory sling surgery, with high rates of positive outcomes. Although this procedure uses minimally invasive surgery principles, postoperative complications have been reported, including bladder dysfunction, urinary retention, erosion and extrusion of the synthetic mesh, and more rarely, abscess formation and fistulization ${ }^{4}$. No statistics were found concerning mesh infection in this type of procedure; for comparison, it is known that after laparoscopic surgical repair of inguinal hernia, the rate of mesh infection is lower 
than $0.5 \%$.

Fistulas are typically late complications, with rare reports of vaginocutaneous fistulas ${ }^{4,6,7}$ and a single report of vaginofemoral fistula in literature ${ }^{8}$. We did not find any report of vaginocutaneous fistulas from abscesses caused by NTM, as reported in this study. The composition of the sling meshes is one of the reasons to worry about the formation of fistulas, since it determines the piece's potential to internally erode the urinary tract and vagina, in addition to a certain degree of bacterial colonization. Individual patient characteristics, such as age, estrogenic status and sexual activity can also influence the likelihood of mesh erosion $^{4,6}$. Risk factors for mesh erosion and fistulization include a history of pelvic irradiation, presence of cancer, infection and menopause ${ }^{6}$.

In cases of mycobacterial mesh infection, the source may be the mesh itself or the transient presence of these pathogens in the surgical environment ${ }^{9}$. The clinical suspicion of infection with non-tuberculous mycobacteria is favored by the presence of chronic lesions that do not resolve $^{1}$. Typically, these infections have long incubation periods ${ }^{10}$. The few cases described in the literature show us that suspicion of fistula formation should rise in patients presenting with bothersome vaginal or cutaneous discharge after transobturator mesh insertion; as described by Abdallah at $\mathrm{al}^{6}$.

The Mycobacterium avium complex (MAC) is a serological complex of 28 serotypes of two species, M. avium and $\mathrm{M}$. intracellulare, which are ubiquitous in the environment and can be isolated from natural sources of water, pools, soil, plants and dust ${ }^{11}$. This group includes potentially pathogenic and non-pathogenic serotypes of extremely slow growth, and is the most important group of opportunistic pathogenic bacteria classified as NTM, exhibiting an epidemiological rise worldwide ${ }^{12}$. Most commonly, they cause infection in patients with AIDS or other immunodeficiency condition, although cases have already been reported in immunocompetent individuals ${ }^{13,14,15}$.
The virulence of MAC is due to several pathogenic mechanisms. These bacteria are able to adhere to and invade epithelial cells, bind to mucus, evade the bactericidal mechanisms of macrophages and multiply within them until killed, and inhibit the proliferation of lymphocytes ${ }^{16}$. This allows the succession of the stages of a chronic inflammation that will eventually form caseous or noncaseous granulomas. However, the most common clinical presentations of this mycobacteriosis are pulmonary, lymphatic and disseminated; skin infections, such as the one presented in this case, are rare. The rare cases reported in the literature of cutaneous abscesses, ulcerations or nodules resulting from MAC infection are generally a result of hematogenous dissemination in immunosuppressed patients ${ }^{11}$. Our patient, however, had no evidence of immunosuppression or disseminated disease.

In the face of a mesh infection, the preferred therapeutic method is a combination of pharmacological treatment and surgical treatment with total removal of the mesh, since the formation of a thick fibrous capsule or biofilm around the mesh prevents the penetration of antimicrobial drugs into the infected site, as in our case ${ }^{5}$. In most cases of erosion, only surgical excision of the exposed portion of the mesh is recommended as the definitive treatment for the condition. However, total excision of the mesh is also suggested to remove as much of the fistulous tract as possible, as in cases of vaginofemoral fistula ${ }^{4,8}$.

\section{FINAL CONSIDERATIONS}

We report a rare case of pelvic abscess with formation of a late fistula with vaginocutaneous tract, due to infection with atypical mycobacteriosis, a rare entity and without description in the literature. Late fistulas originating from pelvic abscesses may be related to displacement or extrusion of meshes such as those of the pelvic sling reported in this case, and it is necessary to raise this hypothesis in order to establish the definitive treatment with pharmacological therapy and surgery, in similar cases.

Contribution of the authors: Each author made significant individual contributions to this manuscript. Teles Filho RV, Abe GM - conducted the literature review and wrote the manuscript. Azevedo LHS, Daldat G - reviewed the manuscript. Teles Filho RV, Daldat $G$ - developed the study concept, were the advisors for the literature review, and performed the final review of the manuscript.

\section{REFERENCES}

1. Chogtu B, Malik DV, Magazine R, Shenoy VP. Mycobacterium fortuitum Infection at Umbilical Hernioplasty Site. J Clin Diagn Res. 2017;11(9):OD01-2. doi: 10.7860/ JCDR/2017/26618.10531.

2. Walang B, Rath S, Sharma S. Nontuberculous mycobacterial infection after frontalis sling surgery using silicone rod. J Ophthalmic Inflamm Infect. 2012;2(4):219-21. doi:10.1007/ s12348-012-0073-y.
3. Davies BW, Bratton EM, Durairaj VD, Hink EM. Bilateral candida and atypical mycobacterial infection after frontalis sling suspension with silicone rod to correct congenital ptosis. Ophthal Plast Reconstr Surg. 2013;29(4):e111-3. doi: 10.1097/IOP.0b013e318281eb1f.

4. Karabulut A, Demitaş Ö, Gök S. A late complication of transobturator tape procedure: vaginocutaneous fistula formation with vaginal mesh erosion. Int Urogynecol J. 2014 Apr 14;25(4):559-61. doi: 10.1007/s00192-013-2193-9. 
5. Ramakrishnan P, Bansal S, Deuri B, Subbiah R, Palanisamy $\mathrm{S}$, Palanivelu PR, et al. A single-centre experience of relaparoscopy in complications of laparoscopic inguinal hernia repair-feasibility and outcomes. Surg Endosc. 2016 Jun 30;30(6):2308-14. doi: 10.1007/s00464-015-4387-3.

6. Abdallah A, Nisolle M, de Landsheere L. Vaginocutaneous fistula and buttock abscess formation 7 years after polypropylene transobturator tape insertion. J Gynecol Obstet Hum Reprod. 2017;46(1):103-5. doi: 10.1016/j. jogoh.2016.11.006.

7. Cho MK, Choi MY, Kim CH. A late complication developing 12 years after a transobturator tape procedure: vulvar abscess with vaginocutaneous fistula. J Obstet Gynaecol (Lahore). 2018;38(1):139-40. doi: 10.1080/01443615.2017.1326888.

8. Reisenauer C, Wietek BM. Vagina-hip fistula after tensionfree transobturator tape placement. Int Urogynecol J. 2015;26(11):1713-4. doi: 10.1007/s00192-015-2726-5.

9. Kannaiyan K, Ragunathan L, Sakthivel S, Sasidar AR, Muralidaran, Venkatachalam GK. Surgical site infections due to rapidly growing mycobacteria in puducherry, India. J Clin Diagn Res. 2015;9(3):DC05-8. doi: 10.7860/ JCDR/2015/10572.5638.

10. Madhusudhan NS, Malini A, Sangma MMB. A case of surgical site infection caused by Mycobacterium fortuitum, following herniorrhaphy. J Clin Diagn Res. 2016 Nov;10(11):DD01-2. doi: 10.7860/JCDR/2016/20045.8924.
11. Inderlied CB, Kemper CA, Bermudez LE. The Mycobacterium avium complex. Clin Microbiol Rev. 1993;6(3):266-310. doi: 10.1128/CMR.6.3.266.

12. Diaco ND, Strohdach B, Falkowski AL, Hainc N, Brunner P, Rutishauser J, et al. Psoas Abscess Due to Mycobacterium avium in A Patient with Chronic Lymphocytic LeukemiaCase Report and Review. J Clin Med. 2019;8(2):216. doi: $10.3390 / \mathrm{jcm} 8020216$.

13. Orme IM, Ordway DJ. Host Response to Nontuberculous Mycobacterial Infections of Current Clinical Importance. Infect Immun. 2014;82(9):3516-22. doi: 10.1128/IAI.01606-13.

14. Nishiuchi Y, Maekura R, Kitada S, Tamaru A, Taguri T, Kira $\mathrm{Y}$, et al. The Recovery of Mycobacterium avium-intracellulare Complex (MAC) from the Residential Bathrooms of Patients with Pulmonary MAC. Clin Infect Dis. 2007;45(3):347-51. doi: 10.1086/519383.

15. Carrasco J, Soto L, Samalvides F, Asencios L, Quispe N, Valencia E. Mycobacterium avium lung infection in HIV/ AIDS patient: first report in Peru. Rev Peru Med Exp Salud Publica. 2014;31(1):156-9. Available from: http://www.ncbi. nlm.nih.gov/pubmed/24718542

16. Reddy VM. Mechanism of Mycobacterium avium complex pathogenesis. Front Biosci. 1998;3(4):d525-31. doi: 10.2741/ a300.

Received: 2020, February 06

Accepted: November 17 